\title{
Thermotoga elfii sp. nov., a Novel Thermophilic Bacterium from an African Oil-Producing Well
}

\author{
G. RAVOT, ${ }^{1}$ M. MAGOT ${ }^{2}$ M.-L. FARDEAU, ${ }^{1}$ B. K. C. PATEL,${ }^{1,3}$ G. PRENSIER, ${ }^{4}$ \\ A. EGAN, ${ }^{3}$ J.-L. GARCIA, ${ }^{1}$ AND B. OLLIVIER ${ }^{1 *}$ \\ Laboratoire de Microbiologie ORSTOM, Université de Provence, 13331 Marseille Cedex $3,{ }^{1}$ Sanofi Recherche, \\ Unité de Microbiologie, 31676 Labège Cedex, ${ }^{2}$ and Laboratoire de Microbiologie, Université \\ Blaise Pascal, 63177 Aubière Cedex, ${ }^{4}$ France, and Faculty of Science and \\ Technology, Griffith University, Nathan 4111, Brisbane, Australia ${ }^{3}$
}

\begin{abstract}
A thermophilic, glucose-fermenting, strictly anaerobic, rod-shaped bacterium, strain SEBR 6459' $(T=$ type strain), was isolated from an African oil-producing well. This organism was identified as a member of the genus Thermotoga on the basis of the presence of the typical outer sheath-like structure (toga) and 16S rRNA signature sequences and its ability to grow on carbohydrates (glucose, arabinose, fructose, lactose, maltose, and xylose). Major differences in its 16S rRNA gene sequence, its lower optimum temperature for growth $\left(66^{\circ} \mathrm{C}\right)$, its sodium chloride range for growth $(0$ to $2.8 \%)$, its lack of lactate as an end product from glucose fermentation, and its peritrichous flagella indicate that strain SEBR $6459^{\mathrm{T}}$ is not similar to the three previously described Thermotoga species. Furthermore, this organism does not belong to any of the other genera related to the order Thermotogales that have been described. On the basis of these findings, we propose that this strain should be described as a new species, Thermotoga elfii. The type strain of $T$. elfii is SEBR 6459 (= DSM 9442).
\end{abstract}

The order Thermotogales currently comprises three genera, Thermotoga (17), Thermosipho (18), and Fervidobacterium (19, 35). All of the species belonging to these genera are rod shaped and have a characteristic outer sheath-like structure which can be observed under in situ conditions (34). Members of the recently described genera Geotoga and Petrotoga (9) also possess this morphological feature and, as determined by a $16 \mathrm{~S}$ rRNA sequence analysis, are distantly related to members of the Thermotogales. Collectively, the five genera mentioned above represent one of the deepest phylogenetic branches in the domain Bacteria (42). These taxa can be differentiated on the basis of their optimum temperatures for growth; Thermotoga species are extreme thermophiles that have optimum temperatures for growth of around $80^{\circ} \mathrm{C}(17$, 20, 21, 41), Thermosipho and Fervidobacterium species have optimum temperatures for growth of 65 to $75^{\circ} \mathrm{C}(18,19,35)$ and are regarded as thermophiles, and Geotoga and Petrotoga species are moderate thermophiles having optimum temperatures for growth of less than $60^{\circ} \mathrm{C}(9)$. Until recently, members of the three genera belonging to the order Thermotogales (Thermotoga, Thermosipho, and Fervidobacterium) have been isolated only from volcanic aquatic environments. Different species have different sodium chloride requirements and optimum temperatures for growth. These differences reflect the restricted ecological habitats (hydrothermal marine environments, hydrothermal terrestrial environments) from which the organisms were isolated. However, Thermotoga species capable of growth at $85^{\circ} \mathrm{C}$ have recently been isolated from oil wells in the North Sea (39). Davey et al. (9) have also described the isolation of members of two new genera of moderate thermoanaerobes, the genera Petrotoga and Geotoga, from oil fields. These reports have extended our knowl-

\footnotetext{
* Corresponding author. Mailing address: Laboratoire de Microbiologie ORSTOM, Université de Provence, 3 Place Victor Hugo, 13331 Marseille Cedex 3, France. Phone: 33.91.10.64.80. Fax: 33.91.10.64.81.
}

edge concerning the ecological habitats of these bacteria. In this paper, we describe the results of an investigation of a new thermophilic Thermotoga strain isolated from an African oil field and discuss the diversity of similar strains in such environments.

\section{MATERIALS AND METHODS}

Sample collection and sample source. Strain SEBR $6459^{\mathrm{T}}(\mathrm{T}=$ type strain) was isolated from an oil-producing well in Africa. The in situ temperature was $68^{\circ} \mathrm{C}$, and the concentration of sodium chloride was $12 \mathrm{~g} /$ liter. A 1-liter sample was collected at the wellhead as described elsewhere (5). In the laboratory, portions of this sample were inoculated onto culture media.

Enrichment, isolation, and growth conditions. Basal medium MB was used for all studies; this basal medium was modified when necessary, as discussed below. Basal medium MB contained (per liter) $1 \mathrm{~g}$ of $\mathrm{NH}_{4} \mathrm{Cl}, 0.3 \mathrm{~g}$ of $\mathrm{K}_{2} \mathrm{HPO}_{4}, 0.3 \mathrm{~g}$ of $\mathrm{KH}_{2} \mathrm{PO}_{4}, 0.2 \mathrm{~g}$ of $\mathrm{MgCl}_{2} \cdot 6 \mathrm{H}_{2} \mathrm{O}, 0.1 \mathrm{~g}$ of $\mathrm{CaCl}_{2} \cdot 2 \mathrm{H}_{2} \mathrm{O}, 10 \mathrm{~g}$ of $\mathrm{NaCl}, 0.1 \mathrm{~g}$ of $\mathrm{KCl}, 0.5 \mathrm{~g}$ of cysteine- $\mathrm{HCl}, 0.5 \mathrm{~g}$ of sodium acetate (anhydrous), $2 \mathrm{~g}$ of yeas extract (Difco Laboratories, Detroit, Mich.), $2 \mathrm{~g}$ of bio-Trypticase (bioMérieux Graponne, France), $10 \mathrm{ml}$ of the trace mineral element solution of Balch et al. (3), $1 \mathrm{mg}$ of resazurin, and $1,000 \mathrm{ml}$ of distilled water. The $\mathrm{pH}$ was adjusted to 8.0 with $10 \mathrm{M} \mathrm{KOH}$. The medium was boiled under a stream of $\mathrm{O}_{2}$-free $\mathrm{N}_{2}$ gas and cooled to room temperature. Then 5-ml portions of the medium were distributed into Hungate tubes under a stream of $\mathrm{N}_{2}-\mathrm{CO}_{2}(80: 20)$, and the tubes were autoclaved for $45 \mathrm{~min}$ at $110^{\circ} \mathrm{C}$. Just prior to inoculation, $0.1 \mathrm{ml}$ of $\mathrm{Na}_{2} \mathrm{~S} \cdot 9 \mathrm{H}_{2} \mathrm{O}$ (from a $2 \%$ sterile anaerobic stock solution) and $0.1 \mathrm{ml}$ of $\mathrm{Na}_{2} \mathrm{CO}_{3}$ (from a sterile $10 \%$ anaerobic stock solution) were injected into each tube.

For enrichment cultures and isolation, basal medium MB was modified as follows. The medium was dispensed into $20-\mathrm{ml}$ serum vials under a stream of $\mathrm{H}_{2}-\mathrm{CO}_{2}\left(80: 20 ; 2 \times 10^{5} \mathrm{~Pa}\right)$, and thiosulfate (final concentration, $20 \mathrm{mM}$ ) was added as an electron acceptor. An enrichment culture was initiated by injecting $2 \mathrm{ml}$ of a sample, and the preparation was incubated without shaking at $60^{\circ} \mathrm{C}$. An isolate was purified by repeatedly performing the agar shake dilution technique in the same medium containing $2 \%$ Noble agar (Difco), as described previously (33). The purity of each culture was checked by microscopic examination.

pH, temperature, and sodium chloride ranges for growth. For growth studies, the yeast extract and bio-Trypticase concentrations in the basal medium were changed to 1 and $5 \mathrm{~g} /$ /iter, respectively. For $\mathrm{pH}$ studies, the $\mathrm{pH}$ values of media in prereduced anaerobic tubes were adjusted with $\mathrm{NaHCO}_{3}$ or $\mathrm{Na}_{2} \mathrm{CO}_{3}(10 \%$ sterile anaerobic stock solutions). For temperature studies, mineral oil baths were used when incubation temperatures were greater than $50^{\circ} \mathrm{C}$ and water baths were used when the incubation temperatures were less than $50^{\circ} \mathrm{C}$. For growth 
studies in which different salt concentrations were used, sodium chloride was weighed directly in the tubes to give the desired concentrations when concentrations higher than $1 \%$ were used, and the medium was dispensed into the tubes as described above. When sodium chloride concentrations less than $1 \%$ were used, different amounts from a $10 \% \mathrm{NaCl}$ stock solution were injected into the prereduced medium to give the desired concentrations. The strain was subcultured at least once under the same experimental conditions prior to inoculation.

Substrate utilization tests. Tests to determine utilization of substrates were performed in the medium described above containing thiosulfate $(20 \mathrm{mM}), 1 \mathrm{~g}$ of yeast extract per liter, and $1 \mathrm{~g}$ of bio-Trypticase per liter. Substrates were added from sterile anaerobic stock solutions. The electron acceptors thiosulfate, sulfate and elemental sulfur were added to the medium when they were required at concentrations of $20 \mathrm{mM}, 20 \mathrm{mM}$, and $2 \%$, respectively.

Light and electron microscopy. Cells were observed with a Nikon microscope to determine purity, morphology, and the Gram reaction. Phase-contrast microscopy was used when cells were observed unstained. Cells were negatively stained with uranyl acetate $(4 \%$ [wt/vol] in distilled water). For thin-section electron microscopy, exponentially growing cells were fixed for $1 \mathrm{~h}$ in $0.07 \mathrm{M}$ sodium cacodylate buffer ( $\mathrm{pH} 7.3$ ) containing $1.2 \%$ glutaraldehyde and $0.05 \%$ ruthenium red and then in $0.07 \mathrm{M}$ cacodylate buffer ( $\mathrm{pH} 7.3$ ) containing $1 \%$ (wt/vol) osmium tetraoxide. The samples were then embedded in Epon, dehydrated in an ethanol series, and sectioned, and the sections were stained with $2 \%$ uranyl acetate in $50 \%$ ethanol and then with $2 \%$ lead citrate. The sections were observed with a JEOL model $1200 \mathrm{CX}$ electron microscope at an accelerating voltage of $80 \mathrm{kV}$.

Analytical techniques. Unless indicated otherwise, duplicate culture tubes were used throughout this study. Growth was measured by inserting tubes directly into a model UV-160A spectrophotometer (Shimadzu Corp., Kyoto, Japan) and measuring the optical density at $580 \mathrm{~nm}$. Sulfide contents were determined photometrically as collodial CuS by using the method of Cord-Ruwisch

(7). Contents of $\mathrm{H}_{2}$ and fermentation products (alcohols and volatile and nonvolatile fatty acids) were measured as described previously (14).

Determination of $G+C$ content. The $G+C$ content of DNA was determined by workers at DSM-Deutsche Sammlung von Mikroorganismen und Zellkulturen GmbH, Braunschweig, Germany. The DNA was isolated and purified by chromatography on hydroxyapatite. The $G+C$ content was determined by using high-performance liquid chromatography (HPLC) as described by Mesbah et al. (31). Nonmethylated lambda DNA (Sigma) was used as the standard.

16S rRNA sequence studies. Semipurified DNA was extracted for amplification of the 16S rRNA gene by the following protocol. A $20-\mathrm{ml}$ culture was centrifuged, and the resulting pellet was resuspended in $50 \mu$ l of lysis buffer ( 50 $\mathrm{mM}$ Tris- $\mathrm{HCl}$ [pH 7.2], $50 \mathrm{mM}$ EDTA, $3 \%$ sodium dodecyl sulfate) and pipetted into a microcentrifuge tube. The suspension was microwaved on high for fou cycles, each consisting of $15 \mathrm{~s}$ with the heat on and $5 \mathrm{~s}$ with the heat off with an open lid. Then $350 \mu \mathrm{l}$ of lysis buffer was added, the lid was closed, the preparation was incubated at $80^{\circ} \mathrm{C}$ for $15 \mathrm{~min}$, and the suspension was vortexed with $400 \mu \mathrm{l}$ of phenol-chloroform (1:1). The preparation was then centrifuged at $13,000 \times g$ for $15 \mathrm{~min}$ to separate the phases. The top aqueous phase (approximately $200 \mu \mathrm{l}$ ) was removed; we were careful to avoid any material from the interface when we did this. Then $10 \mu \mathrm{l}$ of isopropanol and $5 \mu \mathrm{l}$ of $5 \mathrm{M}$ sodium acetate ( $\mathrm{pH} 5.8$ ) were added to the aqueous phase, and the preparation was vortexed. The suspension was centrifuged at $13,000 \times g$, and the resulting pellet was washed with cold $80 \%$ ethanol, placed in a desiccator to evaporate the residual ethanol, resuspended in $50 \mu \mathrm{l}$ of sterile distilled water, and stored at $-20^{\circ} \mathrm{C}$ until it was used. Amplification of the 16S rRNA gene from the semipurified DNA followed by purification of the amplified product was performed as described previously $(27,37)$. The purified PCR product was sequenced directly with an ABI automated DNA sequencer by using a Prism dideoxy terminator cycle sequencing kit and the protocols recommended by the manufacturer (Applied Biosystems, Ltd., Foster City, Calif.). The primers used for sequencing have been described previously (37).

The $16 \mathrm{~S}$ ribosomal DNA sequence obtained from the sequencing data was aligned by using sequence editor ae 2 with the sequences of various members of the bacterial phylum; the latter 16S rRNA sequences were obtained from the Ribosomal Database Project (version 4.0) (26). Positions of sequence and alignment uncertainty were omitted from the analysis, and pairwise evolutionary distances based on 1,170 unambiguous nucleotides were computed by using the method of Jukes and Cantor (24). Dendrograms were constructed from evolutionary distances by using the neighbor-joining method, a transversion analysis was performed by using the program DNAPARS, and tree topology was examined by using 100 bootstrapped data sets by running the script file DBOOT. For DBOOT we used the following sequence of events during the analysis: SEQBOOT, DNADIST, FITCH, and CONSENSE. All programs are available as part of the PHYLIP package (15). Programs available in the Molecular Evolutionary Genetic Analysis (MEGA) package, version 1 (25), were also used in the analysis. All of the programs except MEGA were run on a Sun Sparc workstation; MEGA was run on a 386 Toshiba model T3100SX laptop IBM-compatible computer.

Nucleotide sequence accession number. The 16S rRNA sequence of strain

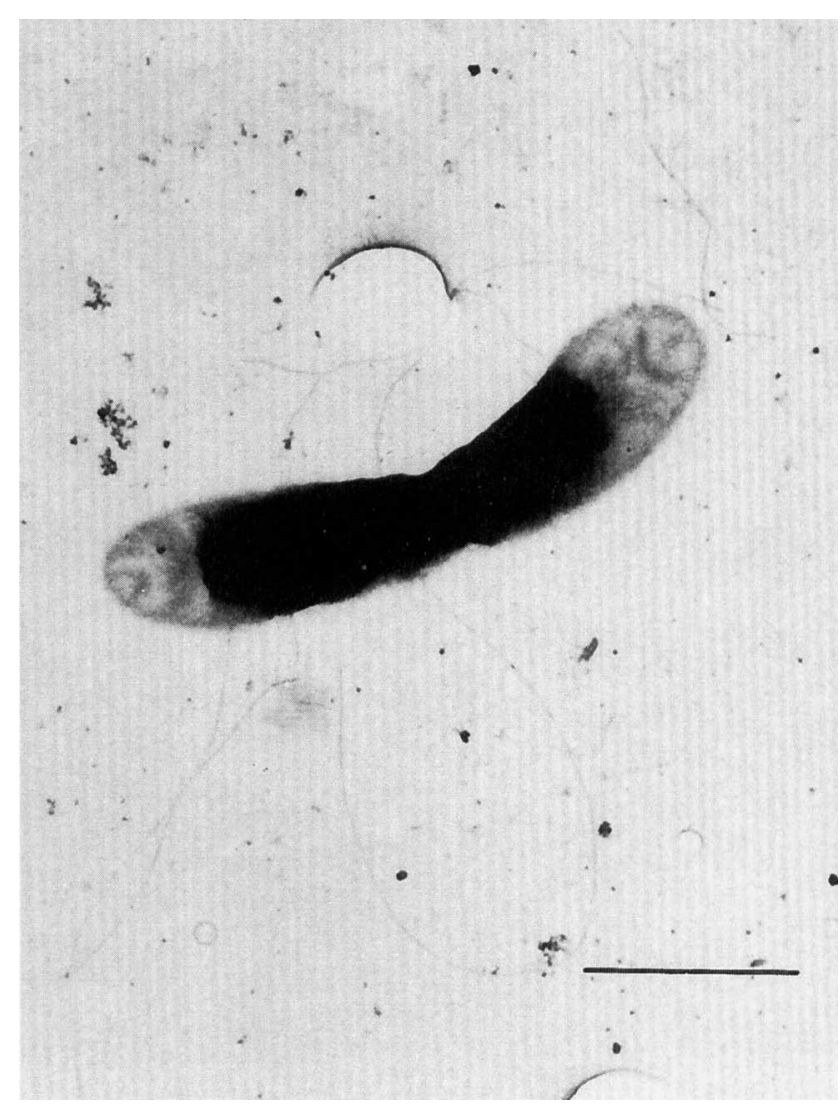

FIG. 1. Electron micrograph of a negatively stained cell of SEBR $6459^{\mathrm{T}}$ showing the typical outer sheath-like structure of the genus Thermotoga. Bar = $1 \mu \mathrm{m}$.

SEBR $6459^{\mathrm{T}}$ determined in this study has been deposited in the EMBL database under accession number X80790.

\section{RESULTS}

Enrichment and isolation. Enrichment cultures were positive after incubation at $60^{\circ} \mathrm{C}$ for 3 days. $\mathrm{H}_{2} \mathrm{~S}$ was also produced from thiosulfate reduction. Microscopic examination revealed the presence of rod-shaped bacteria having an outer sheathlike structure characteristic of members of the Thermotogales (Fig. 1). Enrichment cultures were serially diluted and inoculated into agar shake tubes. Colonies that were $1 \mathrm{~mm}$ in diameter were observed after 7 days of growth at $60^{\circ} \mathrm{C}$. Single colonies were picked, and serial dilution in agar shake tubes was repeated at least twice before the culture was considered pure. We obtained several axenic cultures that had the typical outer polar sheath-like structures found in members of the Thermotogales. A strain designated SEBR $6459^{\mathrm{T}}$ was used for further characterization.

Morphology. Strain SEBR $6459^{\mathrm{T}}$ was a strictly anaerobic, rod-shaped organism. The cells were 0.5 to 1 by 2 to $3 \mu \mathrm{m}$ and occurred singly or in pairs. Strain SEBR $6459^{\mathrm{T}}$ was gram negative and had a typical gram-negative cell wall ultrastructure, as determined by observing thin sections with an electron microscope (Fig. 2). Each cell was surrounded by a characteristic toga, a sheath-like structure ballooning over the ends (Fig. 1), and had peritrichous flagella.

Optimum growth conditions. Strain SEBR $6459^{\mathrm{T}}$ grew at temperatures ranging from 50 to $72^{\circ} \mathrm{C}$; optimum growth occurred at $66^{\circ} \mathrm{C}$. No growth was observed at 45 and $75^{\circ} \mathrm{C}$. This 


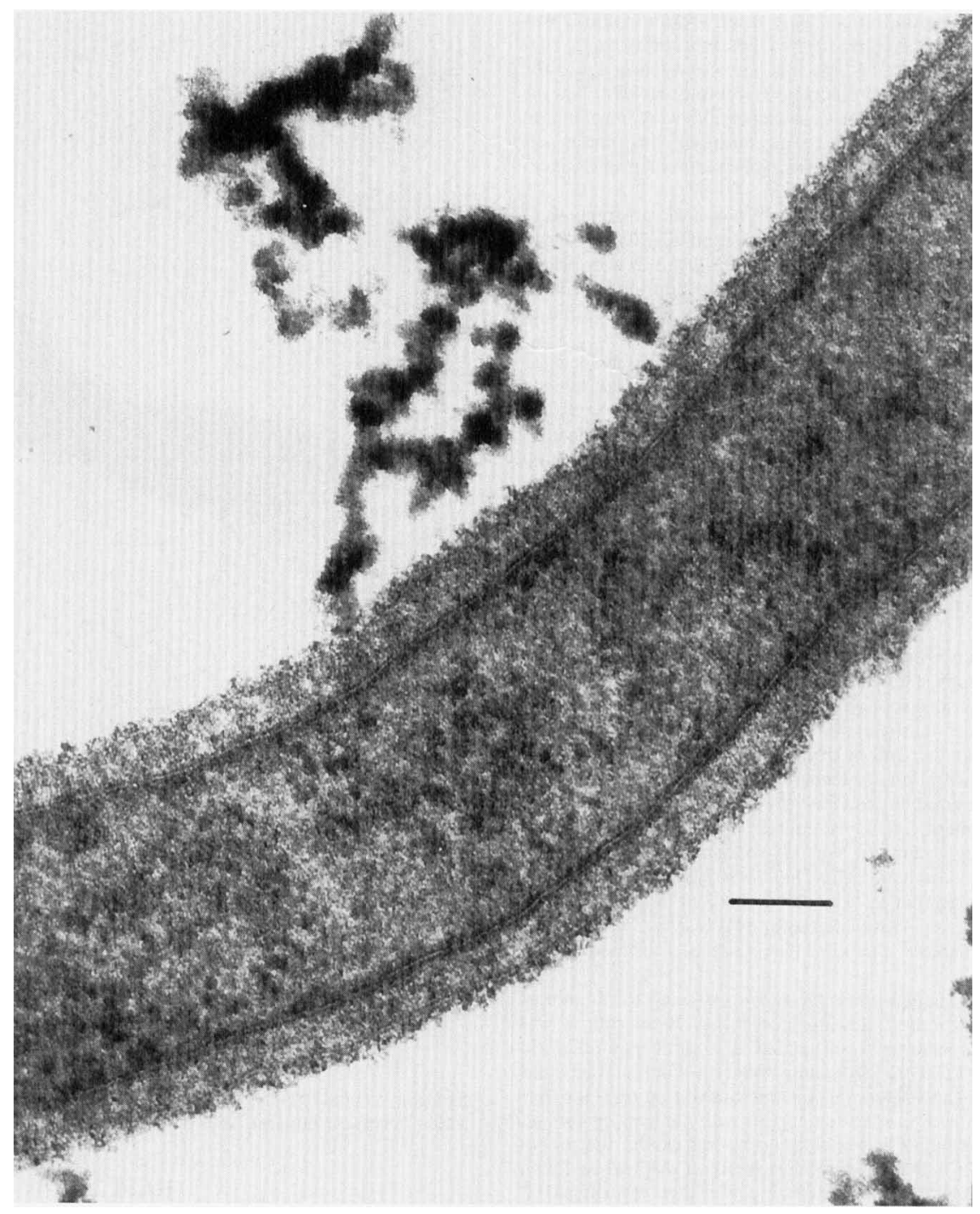

FIG. 2. Thin section of isolate SEBR $6459^{\mathrm{T}}$ showing a typical gram-negative cell wall ultrastructure. Bar $=0.1 \mu \mathrm{m}$.

organism grew in the presence of sodium chloride concentrations ranging from 0 to $2.8 \%$, and optimum growth occurred in the presence of approximately $1 \% \mathrm{NaCl}$. The optimum $\mathrm{pH}$ for growth was 7.5 , and growth occurred at $\mathrm{pH} 5.5$ but not at $\mathrm{pH}$ 9.1. When the temperature, $\mathrm{pH}$, and sodium chloride concentration were optimal, the generation time was $2.8 \mathrm{~h}$.

Substrates used for growth. In the presence of thiosulfate, strain SEBR $6459^{\mathrm{T}}$ was nutritionally versatile and was able to oxidize D-glucose, D-arabinose, D-fructose, lactose, maltose, D-mannose, D-ribose, sucrose, and D-xylose but not L-arabitol, D-mannitol, L-rhamnose, L-sorbose, L-xylose, or fatty acids (acetate, butyrate, lactate, and propionate). Yeast extract $(0.1 \%)$ and bio-Trypticase $(0.1 \%)$ were required for growth. Yeast extract could not be replaced by Casamino Acids, vitamins (40), or a mixture of Casamino Acids and vitamins. During the fermentation of glucose in the absence of thiosulfate, acetate, $\mathrm{CO}_{2}$, and $\mathrm{H}_{2}$ were produced. The isolate was also able to ferment bio-Trypticase in the presence of yeast extract.

Effects of added electron acceptors. The ability of strain SEBR $6459^{\mathrm{T}}$ to use electron acceptors, including sulfate, thiosulfate, and elemental sulfur, was determined by using a medium containing $1 \mathrm{~g}$ of yeast extract per liter and $5 \mathrm{~g}$ of bio-
Trypticase per liter. Strain SEBR $6459^{\mathrm{T}}$ used only thiosulfate as an electron acceptor (Fig. 3). Furthermore, elemental sulfur completely inhibited growth of this organism (Fig. 3). When thiosulfate was added to a medium containing glucose, growth of the isolate increased twofold (Fig. 4). Under these conditions, utilization of glucose was significantly higher than utilization of glucose in the absence of thiosulfate (Table 1). In the presence or absence of thiosulfate, the only fatty acid produced during glucose fermentation was acetate (Table 1).

$\mathbf{G}+\mathbf{C}$ content. The $\mathrm{G}+\mathrm{C}$ content of isolate SEBR $6459^{\mathrm{T}}$ was $39.6 \mathrm{~mol} \%$.

16S rRNA sequence analysis. Using eight primers, we determined an almost complete sequence consisting of 1,519 bases for the 16S rRNA gene of strain SEBR $6459^{\mathrm{T}}$. This sequence (positions 36 to 1,540; Escherichia coli numbering of Winker and Woese [42]) was aligned with the sequences of representatives of the various phyla of the domain Bacteria, and a phylogenetic analysis was performed. This analysis revealed that strain SEBR $6459^{\mathrm{T}}$ was a member of the order Thermotogales. Additional sequence alignments and phylogenetic analyses performed with members of this order indicated that the closest relatives of strain SEBR $6459^{\mathrm{T}}$ were Thermo- 


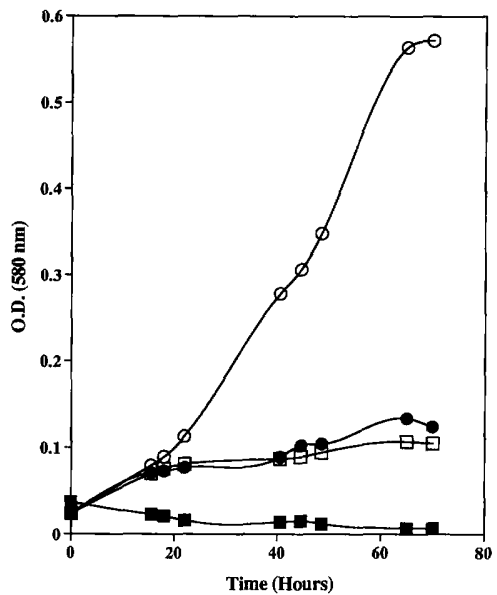

FIG. 3. Effects of different electron acceptors on the growth of strain SEBR $6459^{\mathrm{T}}$. Symbols: - control; $\square$, sulfate $(20 \mathrm{mM}) ; \bigcirc$, thiosulfate $(20 \mathrm{mM})$; elemental sulfur $(2 \%)$. The medium contained $1 \mathrm{~g}$ of yeast extract per liter and $5 \mathrm{~g}$ of bio-Trypticase per liter. O.D. $(580 \mathrm{~nm})$, optical density at $580 \mathrm{~nm}$.

toga maritima and Thermotoga thermarum (average level of similarity, 92\%) and Thermosipho africanus (level of similarity, $90 \%$ ). Strain SEBR $6459^{\mathrm{T}}$ was only distantly related to other members of the Thermotogales and related bacteria, including Fervidobacterium sp. (average level of similarity, 86\%), Petrotoga miotherma, Geotoga subterranea, and Geotoga petraea (average level of similarity, $79 \%$ ) (Table 2). Figure 5 is a dendrogram generated by the neighbor-joining method (15) from a Jukes-Cantor evolutionary similarity matrix (24) (Table 2) and shows this relationship.

Strain SEBR $6459^{\mathrm{T}}$ is related to Thermotoga thermarum and Thermotoga maritima as shown by identical structural idiosyncrasies (represented by a relatively long helix at positions 184 to 193,450 to 480 , and 1438 to 1463 ) but is distinctly different from Thermosipho, Fervidobacterium, Geotoga, and Petrotoga species. Although strain SEBR $6459^{\mathrm{T}}$, Thermotoga thermarum, and Thermotoga maritima all have identical structural idiosyncrasies in these regions, their sequences are different.

In addition, our parsimony analysis produced the same tree

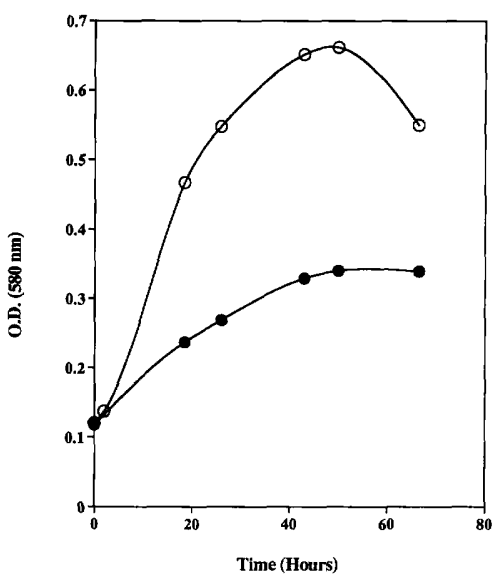

FIG. 4. Effect of thiosulfate on the growth of strain SEBR $6459^{\mathrm{T}}$ cultivated in basal medium MB containing $20 \mathrm{mM}$ glucose, $1 \mathrm{~g}$ of yeast extract per liter, and $1 \mathrm{~g}$ of bio-Trypticase per liter. Symbols: - , no thiosulfate present; $\bigcirc, 20 \mathrm{mM}$ thiosulfate present. O.D. $(580 \mathrm{~nm})$, optical density at $580 \mathrm{~nm}$.
TABLE 1. End products formed during glucose fermentation by Thermotoga elfii in the absence and presence of thiosulfate ${ }^{a}$

\begin{tabular}{lcccc}
\hline Growth conditions & $\begin{array}{c}\text { Amt of } \\
\text { substrate } \\
\text { used } \\
(\mathrm{mM})\end{array}$ & $\begin{array}{c}\text { Amt of } \\
\text { acetate } \\
\text { produced } \\
(\mathrm{mM})\end{array}$ & $\begin{array}{c}\text { Amt of } \\
\mathrm{H}_{2} \\
\text { produced } \\
(\mathrm{mM})\end{array}$ & $\begin{array}{c}\text { Amt of } \\
\mathrm{H}_{2} \mathrm{~S} \\
\text { produced } \\
(\mathrm{mM})\end{array}$ \\
\hline Glucose & 3.1 & 4.0 & 8.8 & 0 \\
Glucose + thiosulfate & 10.4 & 17.9 & 2.0 & 23.0 \\
\hline
\end{tabular}

${ }^{a}$ Basal medium MB contained $1 \mathrm{~g}$ of yeast extract per liter, $1 \mathrm{~g}$ of bioTrypticase per liter, and $20 \mathrm{mM}$ glucose. The amounts of volatile fatty acids, $\mathrm{H}_{2}$, and $\mathrm{H}_{2} \mathrm{~S}$ produced in the same medium in the absence of glucose were subtracted when we calculated the amounts of products formed during glucose fermentation.

topology, but our bootstrap analysis revealed a low level of relatedness $(60 \%)$. The level of relatedness might be increased by isolating and sequencing the $16 \mathrm{~S}$ rRNA genes of more Thermotoga species, a task which is currently being undertaken in our laboratories.

\section{DISCUSSION}

Oil fields represent a novel environment with respect to their physicochemical conditions (halophilic, thermophilic, mesophilic) and therefore provide an exciting source from which taxonomically, physiologically, and phylogenetically unusual microbes can be isolated. Some of these isolates may be useful in microbe-enhanced oil recovery processes $(6,30)$. The new thermophilic, anaerobic, heterotrophic microbe isolate SEBR $6459^{\mathrm{T}}$ from an African oil field extends the physiological and taxonomic diversity of thermophiles that have been obtained from deep subsurface environments. Previous microbiological studies of such environments have led to the identification of several thermophilic microbes, including anaerobic fermenters $(14,36)$, homoacetogens (11), sulfate-reducing bacteria (1), methanogens $(4,10,32)$, and sulfur-reducing anaerobes (39), but not any isolate similar to the organism described in this paper.

It is thought that oil pipeline biofouling and corrosion are microbially mediated, and sulfate-reducing bacteria have been implicated as the major causative agents $(12,13,16)$. Stetter et al. (39) have demonstrated that numerous sulfur-reducing hyperthermophilic bacteria which do not use sulfate as an electron acceptor are present in oil fields. The isolation from an oil field of strain SEBR $6459^{\mathrm{T}}$, an organism that can utilize thio-

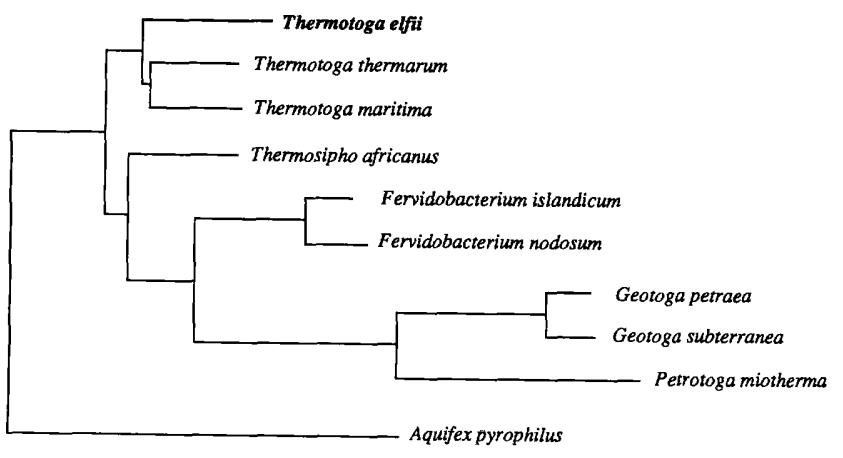

$10 \%$

FIG. 5. Phylogenetic position of Thermotoga elfi within the Thermotogales. Bar $=$ evolutionary distance of $10 \%$. 
TABLE 2. Evolutionary similarity matrix for members of the Thermotogales determined by using the method of Jukes and Cantor ${ }^{a}$

\begin{tabular}{|c|c|c|c|c|c|c|c|c|c|}
\hline \multirow[b]{2}{*}{ Species } & \multicolumn{9}{|c|}{$\%$ Similarity } \\
\hline & 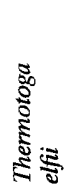 & 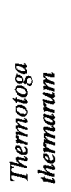 & 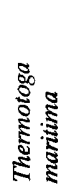 & 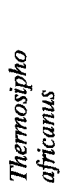 & 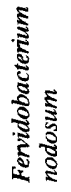 & 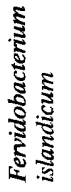 & 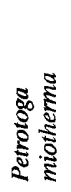 & 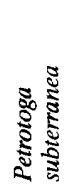 & 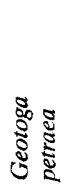 \\
\hline Thermotoga thermarum & 92.6 & & & & & & & & \\
\hline Thermotoga maritima & 91.9 & 93.8 & & & & & & & \\
\hline Thermosipho africanus & 90.3 & 91.5 & 90.9 & & & & & & \\
\hline Fervidobacterium nodosum & 85.6 & 86.7 & 87.0 & 88.3 & & & & & \\
\hline Fervidobacterium islandicum & 86.5 & 87.4 & 87.3 & 89.5 & 96.1 & & & & \\
\hline Petrotoga miotherma & 78.5 & 77.8 & 78.8 & 79.6 & 80.8 & 80.5 & & & \\
\hline Petrotoga subterranea & 79.7 & 79.9 & 80.8 & 81.1 & 81.9 & 81.4 & 85.0 & & \\
\hline Geotoga petraea & 79.8 & 79.8 & 80.7 & 80.9 & 82.0 & 81.5 & 85.5 & 96.6 & \\
\hline Aquifex pyrophilus & 78.7 & 80.3 & 81.4 & 77.8 & 77.3 & 76.7 & 71.9 & 73.2 & 73.0 \\
\hline
\end{tabular}

${ }^{a}$ See Materials and Methods. The sequences used in this analysis were obtained from the Ribosomal Database Project, version 4.0 (26). Only 1,170 unambiguous nucleotide positions were used in this analysis.

sulfate but not sulfate or elemental sulfur as an electron acceptor and produces $\mathrm{H}_{2} \mathrm{~S}$, raises some interesting questions about the involvement of such thermophilic sulfide producers in the process of biocorrosion in oil fields. Indeed, it has been recently hypothesized that thiosulfate, which results from chemical oxidation of sulfide $(22,23,29)$, could increase the risk of corrosion $(8,28)$.

Isolate SEBR $6459^{\mathrm{T}}$ is an anaerobic, rod-shaped thermophile with an outer sheath-like structure that is characteristic of genera belonging to the order Thermotogales. This sheathlike flattened structure is marginally wider than the diameter of the cell and is referred to as a toga. The toga is a common feature of members of the genera Thermosipho, Geotoga, Petrotoga, and Thermotoga and is distinctly different from the spheroids of Fervidobacterium species $(19,35)$; the latter are spherical and at least six to eight times the diameter of the cell. On the basis of morphological characteristics, isolate SEBR $6459^{\mathrm{T}}$ is not a member of the genus Fervidobacterium $(19,35)$. Strain SEBR $6459^{\mathrm{T}}$ oxidizes carbohydrates and is therefore physiologically different from Thermosipho species (18). Our results indicate that the presence of thiosulfate not only improves glucose oxidation, but also increases the ratio of amount of acetate produced to amount of glucose consumed. On the basis of its optimum temperature for growth and sodium chloride requirements, isolate $\operatorname{SEBR} 6459^{\mathrm{T}}$ is clearly different from Petrotoga and Geotoga species (9). The major evidence that strain SEBR $6459^{\mathrm{T}}$ is different from all other members of the order Thermotogales except Thermotoga neapolitana, Thermotoga maritima, and Thermotoga thermarum comes from a phylogenetic analysis of $16 \mathrm{~S}$ rRNAs. In contrast to Thermotoga neapolitana and Thermotoga maritima, both of which grow at hyperthermophilic temperatures and have an optimum temperature for growth of around $80^{\circ} \mathrm{C}(17,21)$, and Thermotoga thermarum, which also grows at $80^{\circ} \mathrm{C}$ but has a lower optimum temperature for growth $\left(70^{\circ} \mathrm{C}\right)(41)$, strain SEBR $6459^{\mathrm{T}}$ does not grow at $80^{\circ} \mathrm{C}$ and has an optimum temperature for growth of $66^{\circ} \mathrm{C}$.

Thermotoga neapolitana and Thermotoga maritima grow in the presence of 0.25 to $6 \% \mathrm{NaCl}$, whereas Thermotoga thermarum grows in the presence of 0.2 to $0.55 \% \mathrm{NaCl}$; these values reflect the marine and continental habitats of these organisms, respectively. Strain SEBR $6459^{\mathrm{T}}$ has an $\mathrm{NaCl}$ range for growth of 0 to $2.8 \%$ and an optimum $\mathrm{NaCl}$ concentration for growth of around $1 \%$, values which fall between the values obtained for
Thermotoga neapolitana and Thermotoga maritima and the values obtained for Thermotoga thermarum. These concentrations correspond to the in situ concentrations found in the oil field. In addition, the optimum temperature for growth is also close to the temperature found in situ.

Clearly, isolate SEBR $6459^{\mathrm{T}}$ is phenotypically distinct from other Thermotoga species (Table 3). The sequence of the $16 \mathrm{~S}$ rRNA gene of SEBR $6459^{\mathrm{T}}$ also differs significantly $(8 \%)$ from the sequences of the previously described members of the genus Thermotoga. On the basis of the data described above, a new species is warranted $(2,38)$. Thus, we propose that strain SEBR $6459^{\mathrm{T}}$ should be placed in a new species of the genus Thermotoga, Thermotoga elfii.

Description of Thermotoga elfii sp. nov. Thermotoga elfii (el.fi'i. L. gen. n. elfii, named after Elf-Aquitaine). Round colonies (diameter, $1 \mathrm{~mm}$ ) are present after 7 days of incubation at $60^{\circ} \mathrm{C}$. Cells are rods $(0.5$ to 1 by 2 to $3 \mu \mathrm{m})$, and each cell has an outer sheath-like structure (toga). The cells occur singly or in pairs and have peritrichous flagella. The cell wall is gram negative, as determined by electron microscopy or Gram staining. Chemoorganotrophic and obligately anaerobic members of the domain Bacteria. The optimum temperature for growth is $66^{\circ} \mathrm{C}$. No growth occurs at 45 or $75^{\circ} \mathrm{C}$. The optimum $\mathrm{pH}$ is 7.5; growth occurs at $\mathrm{pH} 5.5$ but not at $\mathrm{pH} 9.1$. The optimum sodium chloride concentration for growth is around $1 \%$; only marginal growth occurs in the absence of sodium chloride, and no growth occurs in the presence of $2.8 \% \mathrm{NaCl}$. Oxidizes D-glucose, D-arabinose, D-fructose, lactose, maltose, $D$-mannose, D-ribose, sucrose, and D-xylose in the presence of thiosulfate but not L-arabitol, D-mannitol, L-rhamnose, L-sorbose, L-xylose, acetate, butyrate, lactate, or propionate. Requires yeast extract and bio-Trypticase for growth. Yeast extract cannot be replaced by Casamino Acids, a vitamin solution, or a mixture of Casamino Acids and vitamins. BioTrypticase can be fermented in the presence of yeast extract. The end products of glucose fermentation in the presence of yeast extract and bio-Trypticase are acetate, $\mathrm{CO}_{2}$, and hydrogen. Uses thiosulfate as an electron acceptor during glucose fermentation, and under these conditions the cell density is greater than the cell density when the organism is grown with no added electron acceptor. $\mathrm{H}_{2} \mathrm{~S}$ is produced from thiosulfate reduction. Elemental sulfur cannot be used as an electron acceptor, and growth is inhibited by elemental sulfur. The $\mathrm{G}+\mathrm{C}$ content of the DNA is $39.6 \mathrm{~mol} \%$ (as determined by 


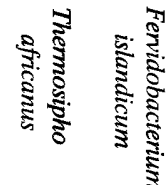

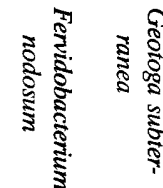

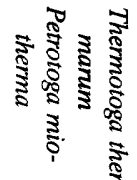

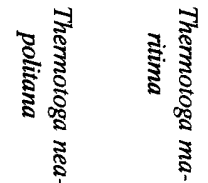

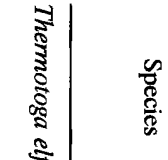

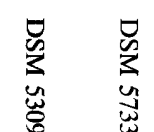

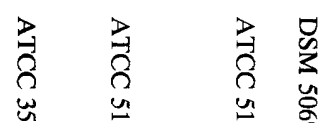

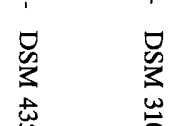

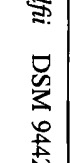

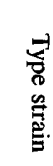

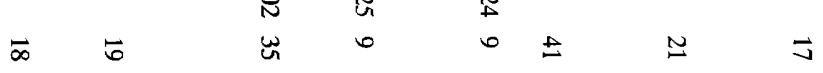

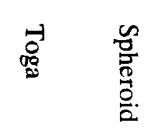

$\frac{\sqrt{2}}{\mathscr{0}}$

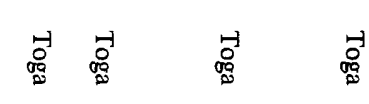

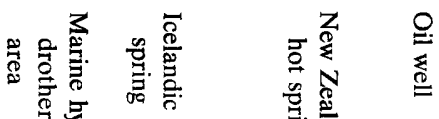

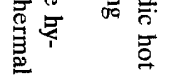

壱.

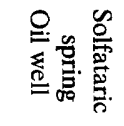

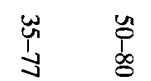

ț

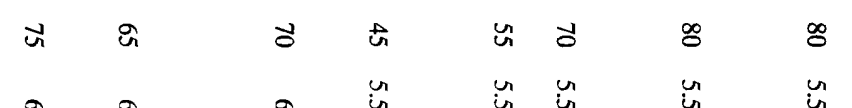

בิ

$\omega$ u in u 4

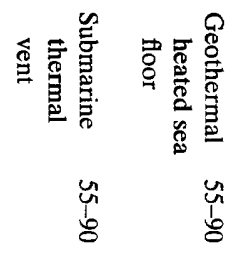

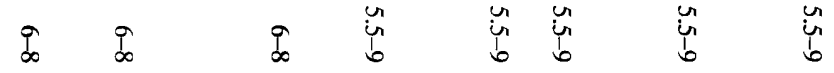

$\vec{n} \quad$ i

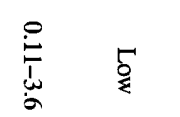

$\checkmark$ in

in

ร

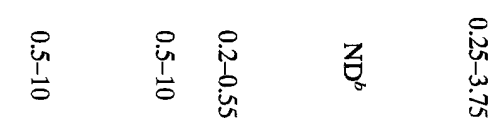

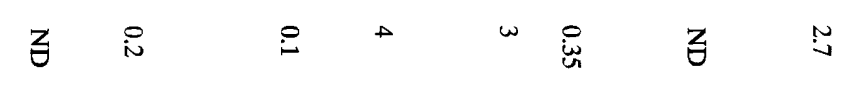

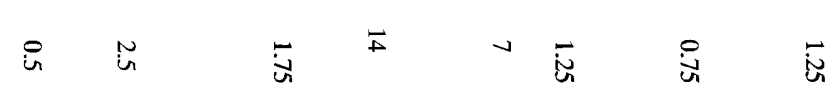

$\tilde{0} \pm$

$\underset{\omega}{\omega} \quad \dot{\sigma} \quad t \quad t \quad t$

$\begin{array}{ll}+ & + \\ z & z\end{array}$

$\begin{array}{ll}z & + \\ z & z\end{array}$

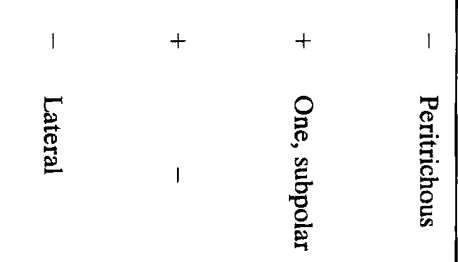

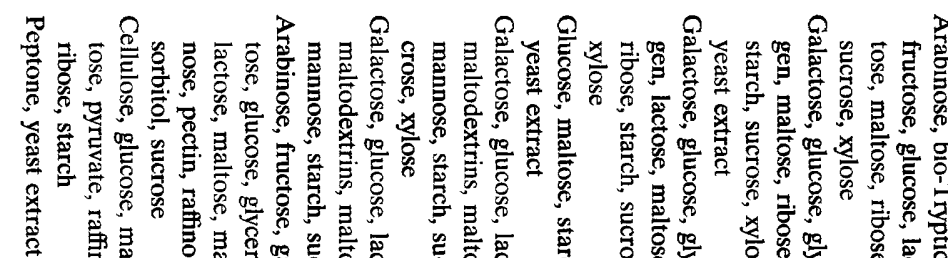

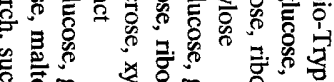

茎

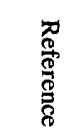

율율

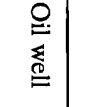

है

.

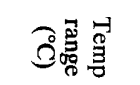

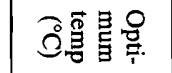

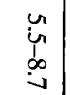

善茫

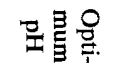

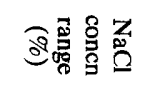

i

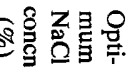

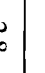

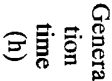

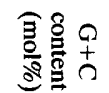

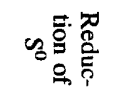

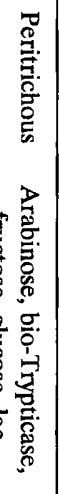

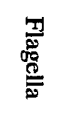

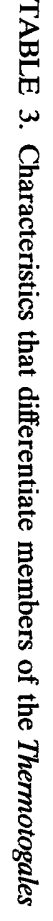

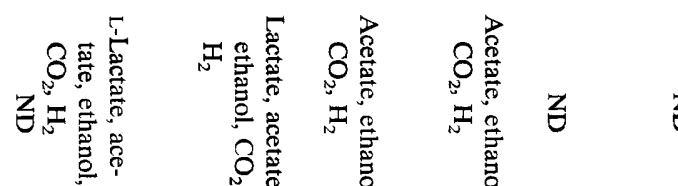

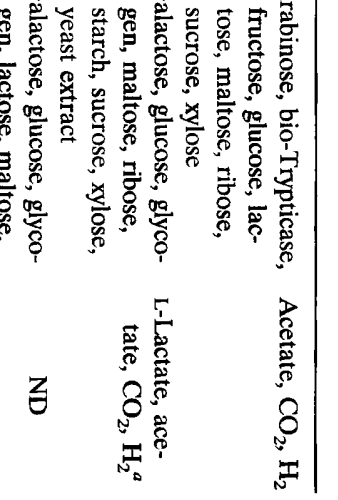

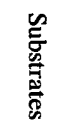

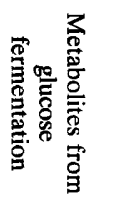


HPLC). Isolated from an oil-producing well. The type strain is SEBR 6459 (= DSM 9442).

\section{ACKNOWLEDGMENTS}

We are indebted to J.-L. Cayol for helpful discussions. G.R.).

This research was supported by a grant from Elf Aquitaine (to

\section{REFERENCES}

1. Adkins, J. P., L. A. Cornell, and R. S. Tanner. 1992. Microbial composition of carbonate petroleum reservoir fluids. Geomicrobiol. J. 10:87-97.

2. Amann, R. I., C. Lin, R. Key, L. Montgomery, and D. A. Stahl. 1992 Diversity among Fibrobacter strains: towards a phylogenetic classification. Syst. Appl. Microbiol. 15:23-31.

3. Balch, W. E., G. E. Fox, R. J. Magrum, and R. S. Wolfe. 1979. Methanogens: reevaluation of a unique biological group. Microbiol. Rev. 43:260-296.

4. Belyaev, S. S., R. Wolkin, W. R. Kenealy, M. J. DeNiro, S. Epstein, and J. G. Zeikus. 1983. Methanogenic bacteria from the Bondyuzhskoe oil field: general characterization and analysis of stable-carbon isotopic fractionation. Appl. Environ. Microbiol. 45:691-697.

5. Bernard, F. P., J. Connan, and M. Magot. 1992. Indigenous microorganisms in connate water of many oil fields: a new tool in exploration and production techniques, paper SPE24811, p. 467-476. In Proceedings of the 67th Annual Technical Conference and Exhibition of the Society of Petroleum Engineers. Society of Petroleum Engineers Inc., Richardson, Tex.

6. Bhupathiraju, V. K., and M. J. McInerney. 1993. Pretest studies for a microbially enhanced oil recovery field pilot in a hypersaline oil reservoir. Geomicrobiol. J. 11:19-34.

7. Cord-Ruwisch, R. 1985. A quick method for the determination of dissolved and precipitated sulfides in cultures of sulfate-reducing bacteria. J. Microbiol. Methods 4:33-36.

8. Crolet, J. L., S. Daumas, and M. Magot. 1993. pH regulation by sulfatereducing bacteria, paper 303, p. 1-170. In Corrosion 93. National Association of Corrosion Engineers, Houston, Tex.

9. Davey, M. E., W. A. Wood, R. Key, K. Nakamura, and D. A. Stahl. 1993. Isolation of three species of Geotoga and Petrotoga: two new genera, representing a new lineage in the bacterial line of descent distantly related to the "Thermotogales." Syst. Appl. Microbiol. 16:191-200.

10. Davydova-Charakhch'yan, I. A., V. G. Kuznetsova, L. L. Mityushina, and S. S. Belayaev. 1993. Methane-forming bacilli from oil fields of Tartaria and western Siberia. Microbiology (Engl. Transl. Mikrobiologiya) 61:202207.

11. Davydova-Charakhch'yan, I. A., A. N. Mileeva, L. L. Mityushina, and S. S. Belayaev. 1993. Acetogenic bacteria from oil fields of Tataria and western Siberia. Microbiology (Engl. Transl. Mikrobiologiya) 61:208-216.

12. De Araujo-jorge, T. C., C. M. L. Melo Coutinho, and L. E. Vargas De Aguiar. 1992. Sulphate-reducing bacteria associated with biocorrosion: a review. Mem. Inst. Oswaldo Cruz Rio de Janeiro 87:329-337.

13. Dzierzewicz, Z., B. Cwalina, L. Weglarz, and S. Glab. 1992. Isolation and evaluation of corrosive aggressivity of wild strains of sulphate-reducing bacteria. Acta Microbiol. Pol. 41:211-221.

14. Fardeau, M. L., J. L. Cayol, M. Magot, and B. Ollivier. 1993. $\mathrm{H}_{2}$ oxidation in the presence of thiosulfate, by a Thermoanaerobacter strain isolated from an oil-producing well. FEMS Microbiol. Lett. 113:327-332.

15. Felsenstein, J. 1993. PHYLIP (phylogenetic inference package), version 3.51c. Department of Genetics, University of Washington, Seattle.

16. Ferris, F. G., T. R. Jack, and B. J. Bramhill. 1992. Corrosion products associated with attached bacteria at an oil field water injection plant. Can. J. Microbiol. 38:1320-1324.

17. Huber, R., T. A. Langworthy, H. König, M. Thomm, C. R. Woese, U. W. Sleytr, and K. O. Stetter. 1986. Thermotoga maritima sp. nov. represents a new genus of unique extremely thermophilic eubacteria growing up to $90^{\circ} \mathrm{C}$. Arch. Microbiol. 144:324-333.

18. Huber, R., C. R. Woese, T. A. Langworthy, H. Fricke, and K. O. Stetter. 1989. Thermosipho africanus gen. nov. represents a new genus of thermophilic eubacteria within the "Thermotogales." Syst. Appl. Microbiol. 12:32-37.

19. Huber, R., C. R. Woese, T. A. Langworthy, J. K. Kristjansson, and K. O. Stetter. 1990. Fervidobacterium islandicum sp. nov., a new extremely ther- mophilic eubacterium belonging to the "Thermotogales." Arch. Microbiol. 154:105-111.

20. Huser, B. A., B. K. C. Patel, H. W. Morgan, and R. M. Daniel. 1986. Isolation and characterization of a novel extremely thermophilic, anaerobic chemoorganotrophic eubacterium. FEMS Microbiol. Lett. 37:121-127.

21. Jannasch, H. W., R. Huber, S. Belkin, and K. O. Stetter. 1988. Thermotoga neapolitana sp. nov. of the extremely thermophilic, eubacterial genus Thermotoga. Arch. Microbiol. 150:103-104.

22. Jorgensen, B. B. 1990 . A thiosulfate shunt in the sulfur cycle of marine sediments. Science 249:152-154.

23. Jorgensen, B. B., and F. Bak. 1991. Pathways and microbiology of thiosulfate transformations and sulfate reduction in a marine sediment (Kattegat, Denmark). Appl. Environ. Microbiol. 57:847-856.

24. Jukes, T. H., and C. R. Cantor. 1969. Evolution of protein molecules, p. 21-132. In H. N. Munro (ed.), Mammalian protein metabolism. Academic Press, New York.

25. Kumar, S., K. Tamura, and M. Nei. 1993. MEGA: molecular evolutionary genetic analysis, version 1.0. The Pennsylvania State University, University Park.

26. Larsen, N., G. J. Olsen, B. L. Maidak, M. J. McCaughey, R. Overbeek, T. J. Macke, T. L. Marsh, and C. R. Woese. 1993. The Ribosomal Database Project. Nucleic Acids Res. 21(Suppl.):3021-3023.

27. Love, C. A., B. K. C. Patel, P. D. Nichols, and E. Stackebrandt. 1993. Desulfotomaculum australicum sp. nov., a thermophilic sulfate-reducing bacterium isolated from the Great Artesian Basin of Australia. Syst. Appl. Microbiol. 16:244-251.

28. Magot, M., L. Carreau, J. L. Cayol, B. Ollivier, and J. L. Crolet. Sulphideproducing, not sulphate-reducing anaerobic bacteria presumptively involved in bacterial corrosion. In C. A. C. Sequeira (ed.), Proceedings of the 3 rd European Federation of Corrosion Workshop on Microbiol Corrosion, in press. The Institute of Materials, London.

29. Marschall, C., P. Frenzel, and H. Cypionka. 1993. Influence of oxygen on sulfate-reduction and growth of sulfate-reducing bacteria. Arch. Microbiol. 159:168-173.

30. McInerney, M. J., and D. W. S. Westlake. 1990. Microbially enhanced oil recovery, p. 409-455. In H. L. Ehrlich and C. L. Brierley (ed.), Microbial mineral recovery. McGraw Hill, New York.

31. Meshab, M., U. Premchandran, and W. B. Whitman. 1989. Precise measurement of the $\mathrm{G}+\mathrm{C}$ content of deoxyribonucleic acid by high-performance liquid chromatography. Int. J. Syst. Bacteriol. 39:159-167.

32. Ng, T. K., P. J. Weimer, and L. J. Gawel. 1989. Possible nonanthropogenic origin of two methanogenic isolates from oil-producing wells in the San Miguelito field, Ventura County, California. Geomicrobiol. J. 7:185-192.

33. Ollivier, B., R. A. Mah, J. L. Garcia, and R. Robinson. 1985. Isolation and characterization of Methanogenium aggregans sp. nov. Int. J. Syst. Bacteriol. 35:127-130.

34. Patel, B. K. C., C. Chalcroft, H. W. Morgan, and R. M. Daniel. 1989. Ultra-structural studies of hot spring bacteria in situ. Syst. Appl. Microbiol. 8:187-193.

35. Patel, B. K. C., H. W. Morgan, and R. M. Daniel. 1985. Fervidobacterium nodosum gen. nov. and spec. nov., a new chemoorganotrophic, caldoactive, anaerobic bacterium. Arch. Microbiol. 141:63-69.

36. Pedersen, K. 1993. The deep subterranean biosphere. Earth Sci. Rev. 34: 243-260.

37. Redburn, A. C., and B. K. C. Patel. 1993. Phylogenetic analysis of Desulfotomaculum thermobenzoicum using polymerase chain reaction-amplified $16 \mathrm{~S}$ rRNA-specific DNA. FEMS Microbiol. Lett. 113:81-86.

38. Stackebrandt, E., and B. M. Goebel. 1994. Taxonomic note: a place for DNA-DNA reassociation and 16S rRNA sequence analysis in the present species definition in bacteriology. Int. J. Syst. Bacteriol. 44:846-849.

39. Stetter, K. O., R. Huber, E. Blochl, M. Kurr, R. D. Eden, M. Fielder, H. Cash, and I. Vance. 1993. Hyperthermophilic Archaea are thriving in deep North Sea and Alaskan reservoirs. Nature (London) 365:743-745.

40. Widdel, F. 1980. Anaerobacter abbau von Fettsäuren und Benzosäure durch neu isolierte Arten sulfatreduzierender Bakterien. Ph.D. thesis. University of Gottingen, Gottingen, Germany.

41. Windberger, E., R. Huber, A. Trincone, H. Fricke, and K. O. Stetter. 1989. Thermotoga thermarum sp. nov. and Thermotoga neapolitana occurring in African continental solfataric springs. Arch. Microbiol. 151:506-512.

42. Winker, S., and C. R. Woese. 1991. A definition of the domains Archaea, Bacteria and Eucarya in terms of small subunit ribosomal RNA characteristics. Syst. Appl. Microbiol. 13:161-165. 